\title{
Pelatihan Learning Management System Berbasis E-Learning Bagi Guru Yang Tergabung Dalam MGMP IPS SMP Kabupaten Ogan Ilir Sumatra Selatan.
}

\author{
Ali Ibrahim ${ }^{1}$, Samsuryasi $^{2}$, Ahmad Rifai ${ }^{4}$,Yadi Utama ${ }^{5}$, \\ ${ }^{1}$ Jurusan Sistem Informasi dan Teknik informatika Fasilkom Unsri \\ 3,4,5 Jurusan Sistem Informasi Fasilkom Unsri, \\ ${ }^{2}$ Jurusan Teknik Informatika Fasilkom Unsri.
}

Email: aliibrahim@unsri.ac.id; samsuryadi@gmail.com; rifai.bae@gmail.com; yadiutama@unsri.ac.id

\begin{abstract}
ABSTRAK
Kegiatan Pelatihan Learning Management System Berbasis E-Learning Bagi Guru Yang Tergabung Dalam MGMP IPS SMP Kabupaten Ogan Ilir Sumatra Selatan merupakan kegiatan atas permintaan dari MGMP melalui ketua MGMP untuk diadakan pelatihan. Kegiatan ini bertujuan untuk berbagi ilmu kepada guru-guru dalam hal membuat media ajar berbasis animasi dan di upload ke e-learning. Selain itu tujuan pembuatan media pembelajaran dengan berbasis animasi adalah supaya dapat menarik dan meningkatkan minat siswa dalam belajar dan memahami materi. Kegiatan pelatihan ini diikuti oleh kurang lebih \pm 20 peserta yang tersebar di SMP yang tergabung dalam SMP MGMP IPS Ogan Ilir. Alhamdulillah pelatihan ini dapat berjalan sesuai dengan harapan, hal ini dapat dilihat daru antusiasme peserta dalam mengikuti pelatihan. Dari hasil pengamatan dan hasil diskusi secara langsung pada saat pelatihan, terlihat bahwa peserta sangat senang mengikuti pelatihan, karena sesuai dengan pendapat beberapa peserta bahwa penggunaan metode ini merupakan cara yang sangat menarik dan mereka yakin akan dapat meningkatkan minat belajar siswa. Selama kegiatan pelatihan berlangsung, peserta dengan mudah dan dapat mengikuti pelatihan karena didukung dengan modul yang jelas dan detail, sehingga peserta dapat dengan mudah mencoba dan membuat bahan ajar dengan program animasi movie maker. Dari hasil pengamatan tim secara langsung sekitar $80 \%$ peserta dinyatakan berhasil dengan baik, karena peserta sudah dapat mencoba sendiri pada saat di beri latihan. Sedangkan $20 \%$ nya peserta masih melihat modul untuk membuat bahan ajar tersebut. Dari hasil diskusi dengan peserta, beberapa peserta menyampaikan bahwa setelah selesai dari pelatihan ini, mereka akan menyebarkan cara ini ke guru lain di masing-masing sekolah. Bahkan mereka berinisiatif untuk mengadakan pelatihan di sekolah mereka masing-masing.
\end{abstract}

Kata Kunci: ICT, Moodel, Elearning, IPS

61 www.jurnal.umb.ac.id 


\section{PENDAHULUAN}

Secara kuantitatif MGMP IPS SMP Kabupaten Ogan Ilir merupakan wadah yang terorganisasi non struktural dari Dinas Pendidikan Kabupaten Ogan Ilir, bagi guru SMP baik negeri maupun swasta dibidang ilmu IPS, untuk meningkatkan kompetensi dan profesionalismenya. MGMP IPS SMP Berdiri tanggal 7 Juli 2007 di Indralaya Kabupaten Ogan Ilir Sejak berdiri MGMP IPS SMP telah banyak mengikuti berbagai pelatihan, seminar, workshop dan kunjungankunjungan di berbagai tempat yang berhubungan dengan peningkatan kompetensi anggota dan menmbah wawasan paedagogik serta inovasi pembelajaran yang nantinya akan sangat berguna pada proses pembelajaran dikelas. Anggota yang tersebar dari 75 SMP di seluruh Kabupaten Ogan Ilir, dibagi atas 5 rayon, serta memiliki jumlah anggota sebanyak 85 guru SMP yang mengajar mata pelajaran IPS. Profile dari MGMP IPS SMP dimulai dari pendirian organisasi tersebut pada tahun 2006, yang berkedudukan di Jl. Merdeka Km.53 Tanjung Batu Kecamatan Tanjung Batu Kabupaten Ogan Ilir.

Sistem pembelajaran yang selama ini dilakukan mayoritas masih menggunakan sistem pembelajaran konvensional (faculty teaching) yang biasa disebut ceramah murni atau ceramah dengan menggunakan alat bantu white board (papan tulis), yang kental dengan suasana instruksional dan dirasa kurang sesuai dengan dinamika perkembangan ilmu pengetahuan dan teknologi yang demikian pesat (Dabutar, 2008 : 2). Sistem pembelajaran konvensional kurang fleksibel dalam mengakomodasi perkembangan materi kompetensi karena pendidik harus intensif menyesuaikan materi, selain itu dalam sistem konvensional selalu ada peserta didik yang mengantuk atau malah tertidur dalam kelas, ada juga yang suka membolos hal ini dikarenakan suasana belajar yang membosankan.

Kejadian semacam ini adalah wajar, karena menurut Petersen (2004:3), dalam proses belajar mengajar seorang pendidik menghadapi banyak peserta didik yang masing-masing mempunyai kepribadian, potensi, latar belakang kehidupan, serta masalah belajar yang berbeda tiap peserta didik. Dengan demikian peserta didik dalam menerima dan memahami uraian dari seorang pendidik juga mengalami perbedaan pula sesuai dengan kemampuan daya serap masing-masing. Ada yang cepat menerima dan memahami materi yang disajikan, ada pula yang lambat bahkan ada pula yang sangat lambat sekali, dan tidak menutup kemungkinan ada juga yang tidak dapat memahami walaupun dijelaskan pendidik.

Salah satu cara yang dapat dilakukan untuk memberikan solusi dari masalah tersebut adalah perlu adanya suatu mekanisme tambahan (suplemen) yang dapat digunakan sebagai media pembelajaran tambahan sebagai pendamping guru. Guru dapat membuat sebuah media pembelajaran yang berisi materi-materi yang diajarkan. Didalam media pembelajaran tersebut, guru dapat menuliskan materi dari awal sampai akhir pertemuan, bahkan termasuk contoh soal dan pembahasan, sehingga anak didik dapat belajar secara mandiri dan berulang. Media pembelajaran yang disebut adalah e-learning dengan konsep learning management system. Untuk mencapai proses pembelajaran berbasis e-learning dengan learning management system, maka guru-guru tersebut harus dilatih untuk dapat membuat e-learning dan management kontent pembelajaran.

Dalam pelatihan yang akan dilaksanakan terhadap guru-guru MGMP IPS SMP Kabupaten Ogan Ilir, guru-guru akan diajarkan dan didampingi untuk membuat sebuah sistem pembelajaran 
tambahan berbasis web (e-learining) dengan menggunakan learning management system atau sering disingkat dengn LMS. LMS merupakan kendaraan utama dalam proses pengajaran dan pembelajaran dengan memanfaatkan sebuat perangkat lunak yaitu moodle. Pelatihan tersebut akan menggunkan program LMS Moodle yang berbasis open source, sehingga proses pembelajaran pada dapat dilakukan secara online.

\section{TUJUAN DAN MANFAAT}

Tujuan kegiatan adalah :

1. Memperkenalkan perangkat lunak aplikasi "moodle" sebagai salah satu aplikasi yang dapat mendukung media pembelajaran berbasis E-Learning;

2. Meningkatkan pengetahuan, pemahaman dan ketrampilan guru tingkat SMP MGMP IPS Kabupaten Ogan Ilir dalam hal pembuatan $e$ learing beserta pengembagna kontennya dengan menggunakan program moodle;

3. Sebagai titil awal diterapkannya model pembelajaran dengan basis teknologi informasi dan komunikasi yaitu e-learning;

4. Memanfaatkan fungsi internet dan website sebagai salah satu media penyampaian informasi, khususnya informasi tentang mata pelajaran di lingkup siswa-siswa SMP yang tergabung dalam MGMP IPS SMP Kabupaten Ogan Ilir.

Manfaat dari kegiatan ini adalah:

\section{Bagi Guru}

Kegiatan ini dapat menambah pengetahuan dan pemahaman serta keterampilan para guru tingkat SMP MGMP IPS Kabupaten Ogan Ilir dalam membuat membuat program elearining untuk pembelajaan secara online;

2. Bagi Sekolah
Proses belajar mengajar menjadi lebih interaktif, karena guru SMS MGMP IPS Kabupaten Ogan Ilir menggunakan media pembelajaran interaktif berbasis e-learing;

3. Bagi Fasilkom Unsri

Sebagai bahan masukan tentang pentingnya teknologi informasi khususnya teknologi komputer, yang dapat digunakan dalam pembelajaran, sehingga dalam penyusunan kurikulum dapat dimasukan matakuliah baru berbasis Teknologi Informasi dan Komunikasi (TIK) dan multimedia.

4. Dengan selesai pelatihan tersebut, diharapkan guru-guru dapat mengembangkan kemampuan individu, khususnya dalam hal teknologi informasi dan komunikasi untuk membuat dan mengembangkan e-learning yang berbasis web yang dapat diakses secara bersama;

5. Siswa dan siswi dapat mendapatkan informasi yang tersedia selama 24 jam tanpa batas ruang dan waktu. Sehingga siswa dan siswi dapat mengulang mempelajari sampai dia paham terhadap materi tersebut. Karena dapat dipelajri secara online 24 jam.

\section{TINJAUAN PUSTAKA}

Tinjauan pustaka menguraikan teori, temuan, dan bahan penerapan lain yang diperoleh dari kajian, penelitian sendiri atau pustaka.

\section{Media Pengajaran}

Media adalah wahana penyalur pesan atau informasi belajar atau alat dalam pendidikan. Alat dalam pendidikan didefinisikan sebagai apa saja yang dapat dijadikan sebagai perantara untuk mencapai tujuan pendidikan [1]. Menurut Herman [3] yang termasuk dalam penggunaan media adalah : 
1. Mengenal, memilih dan menggunakan media;

2. Membuat alat Bantu / media pengajaran;

3. Menggunakan dan mengelola laboratorium dalam proses belajar mengajar;

4. Mengembangkan laboratorium;

5. Menggunakan perpustakaan dalam proses belajar mengajar.

Penggunaan media tiada lain adalah untuk mengurangi verbalisme, agar siswa lebih mudah memahami bahan pelajaran yang disajikan. Penggunaan media ini harus disesuaikan dengan tujuan yang diharapkan.

Rendahnya hasil belajar siswa salah satunya disebabkan oleh kurangnya penggunaan media pengajaran. Beberapa argumentasi dan asumsi dibalik rendahnya prestasi [4] adalah :

1. Kurikulum yang padat;

2. Materi pada buku pelajaran yang dirasakan terlalu banyak dan sulit untuk diikuti;

3. Media belajar yang kurang efektif Media pembelajaran adalah alat yang digunakan untuk mempermudah pemahaman suatu konsep yang ingin dicapai dalam pembelajaran. Bentuknya beragam mulai gerakan tubuh seperti jari tangan, sketsa gambar, foto, alat peraga, radio, televisi, multi-media, komputer, sampai teknologi internet;

4. Metode pengajaran yang tradisional dan tidak interaktif;

5. Sistem evaluasi yang buruk.

\section{Media Pembelajaran Berbasis Komputer}

$\begin{array}{rr}\text { Menurut Sudjana dan Rivai [5] ada } \\ \text { beberapa } & \text { keuntungan dalam }\end{array}$

mendayagunakan komputer dalam pembelajaran, yaitu:

1. membangkitkan motivasi kepada siswa dalam belajar;

2. warna, musik, dan grafis animasi dapat menambahkan kesan realisme;

3. menghasilkan penguatan yang tinggi;

4. kemampuan memori memungkinkan penampilan siswa yang telah lampau direkam dan dipakai dalam merencanakan langkah-langkah selanjutnya di kemudian hari;

5. berguna sekali untuk siswa yang lamban;

6. kemampuan daya rekamnya memungkinkan pengajaran individual bisa dilaksanakan;

7. rentang pengawasan guru diperlebar sejalan dengan banyaknya informasi yang disajikan dengan mudah yang diatur oleh guru, dan membantu pengawasan lebih dekat kepada kontak langsung dengan para siswa.

Menurut Arif [6] mengemukakan bahwa untuk menghasilkan suatu media ajar berbasis teknologi informasi yang berkualitas, maka harus memperhatikan prinsip umum dalam pembuatan media pembelajaran tersebut yaitu : mudah dilihat, menarik, sederhana, bermanfaat bagi pelajar, benar dan tepat sasaran, sah dan masuk akal, tersusun secara baik.

\section{Hakekat Pembelajaran IPS}

Ilmu Pengetahuan Sosial (IPS) merupakan salah satu mata pelajaran yang diberikan mulai dari tingkat SD, MI/SLDB sampai SMP/MTS/SMPLB. IPS mengkaji seperangkat peristiwa, fakta, konsep, dan generalisasi yang berkaitan dengan isu sosial. Pada jenjang SMP/MTS mata pelajaran IPS memuat materi Geografi, Sejarah, Sosiologi dan Ekonomi. Melalui mata pelajaran IPS, peserta didik diarahkan untuk menjadi warga negara Indonesia yang demokratis, bertanggung 
jawab, serta warga dunia yang cinta damai [7].

Mata pelajaran Ilmu Pengetahuan Sosial (IPS), sebagai mata pelajaran yang wajib ditempuh oleh peserta didik, merupakan mata pelajaran yang disusun secara sistematis, komprehensif, dan terpadu sebagaimana yang tertuang dalam Permendiknas Nomor 22 Tahun 2006. Pembelajaran IPS yang disusun secara terpadu, memiliki tujuan agar peserta didik dapat memperoleh pemahaman yang lebih luas dan mendalam pada bidang ilmu yang berkaitan.

Oleh sebab itu, pembelajaran IPS di tingkat SMP dan MTs di Indonesia seharusnya menerapkan pembelajaran IPS secara terpadu. Dari berbagai macam pendekatan yang diungkapkan oleh para ahli, maka pada hakikatnya mata pelajaran IPS untuk tingkat SMP dan MTs adalah integrasi dan penyederhanaan dari berbagai macam displin ilmuilmu sosial yang disusun secara sistematis, komprehensif, dan terpadu. Dengan pendekatan tersebut, diharapkan peserta didik dapat memperoleh pemahaman yang lebih luas dan mendalam.

\section{Tujuan Pembelajaran IPS}

Mata pelajaran Ilmu Pengetahuan Sosial (IPS) di SMP dan MTs di Indonesia memiliki salah satu tujuan untuk mengembangkan kesadaran dan kepedulian terhadap masyarakat dan lingkungan sebagaimana yang tertuang dalam Permendiknas No. 22 Tahun 2006. Berdasarkan pendapat NCSS, maka tujuan utama Social Studies ialah mengembangkan kemampuan peserta didik dalam kehidupan bernegara dan menjadikan peserta didik sebagai masyarakat yang demokratis dan mampu bekerja sama dengan masyarakat dunia.

Karateristik mata pelajaran IPS di SMP antara lain sebagai berikut: (1) Ilmu Pengetahuan Sosial merupakan keterpaduan dari unsur-unsur geografi, sejarah, ekonomi, dan sosiologi; (2) Standar Kompetensi dan Kompetensi Dasar IPS berasal dari struktur keilmuan geografi, sejarah, ekonomi, dan sosiologi, yang dikemas sedemikian rupa sehingga dapat dikembangkan menjadi pokok bahasan atau topik (tema) tertentu; (3) Standar Kompetensi dan Kompetensi Dasar IPS juga menyangkut berbagai masalah sosial yang dirumuskan dengan pendekatan interdisipliner dan multidisipliner; (4) Standar Kompetensi dan Kompetensi Dasar dapat menyangkut peristiwa dan perubahan kehidupan masyarakat dengan prinsip sebab akibat, kewilayahan, adaptasi dan pengelolaan lingkungan, struktur, proses dan masalah sosial serta upaya-upaya perjuangan hidup agar survive seperti pemenuhan kebutuhan, kekuasaan, keadilan dan jaminan; (5) Standar Kompetensi dan Kompetensi Dasar IPS menggunakan tiga dimensi (ruang, waktu, dan nilai/moral) dalam mengkaji dan memahami fenomena sosial serta kehidupan manusia secara keseluruhan.

\section{Pembelajaran Konvensional}

Pada dasarnya seorang guru dituntut untuk menguasa berbagai modelmodel pembelajaran, dimana melalui model pembelajaran yang digunakan akan dapat memberikan nilai tambah bagi siswa. Selanjutnya yang tidak kalah penting dari proses pembelajaran adalah hasil belajar yang optimal atau maksimal.

Salah satu model pembelajaran yang masih berlaku dan sangat banyak digunakan oleh guru di banyak sekolah adalah model pembelajaran konvensional. Model ini sebenarnya sudah tidak layak lagi digunakan sepenuhnya dalam suatu proses pengajaran, dan perlu diubah. Untuk mengubah model pembelajaran konvensional tersebut sangat susah bagi guru , karena guru harus memiliki kemampuan dan keterampilan 
menggunakan model pembelajaran yang lain serta kemampuan menggunakan perangkat teknologi informasi.

Menurut Zamroni [8] metode pembelajaran konvensional adalah metode pembelajaran tradisional atau disebut juga dengan metode ceramah, karena sejak dulu metode ini telah dipergunakan sebagai alat komunikasi lisan antara guru dengan anak didik dalam proses belajar dan pembelajaran. Pembelajaran konvensional yang dimaksud adalah pembelajaran yang memiliki kekhasan tertentu, misalnya lebih mengutamakan hapalan daripada pengertian, menekankan kepada keterampilan menghapal, mengutamakan hasil daripada proses, dan pengajaran berpusat pada guru.

Metode mengajar yang lebih banyak digunakan guru dalam pembelajaran konvensional adalah metode ekspositori. Metode ekspositori ini sama dengan cara mengajar yang biasa (tradisional) dipakai pada banyak pengajaran di kelas. Kegiatan dimulai dari penjelasan yang diberikan oleh guru, selanjutnya guru memberikan contoh soal dan penyelesaiannya, kemudian memberi soal-soal latihan, dan siswa disuruh mengerjakan latihan soal tersebut.

Metode ekspositori menitik beratkan pada kegiatan guru yang utama yaitu menerangkan dan siswa mendengarkan atau mencatat apa yang disampaikan guru. Guru pada umumnya mengajar dengan berpedoman pada buku teks atau LKS, dengan mengutamakan metode ceramah dan kadang-kadang tanya jawab. Tes atau evaluasi yang bersifat sumatif dengan maksud untuk mengetahui perkembangan jarang dilakukan. Siswa harus mengikuti cara belajar yang dipilih oleh guru, dengan patuh mempelajari urutan yang ditetapkan guru, dan kurang sekali mendapat kesempatan untuk menyatakan pendapat. Para pengajar jarang mengajar siswa untuk menganalisa secara mendalam tentang suatu konsep dan jarang mendorong siswa untuk menggunakan penalaran logis yang lebih tinggi seperti kemampuan membuktikan atau memperlihatkan suatu konsep.

Model pembelajaran konvensional mengharuskan guru dan siswa terpaku pada jadwal pembelajaran yang telah ditentukan. Ketepatan memanfaatan waktu belajar di kelas sangat berpengaruh terhadap hasil pembelajaran yang dilakukan. Model pembelajaran klasik tersebut juga sangat tergantung dan ditentukan dari seberapa jauh penguasaan materi yang dimiliki oleh tenaga pengaja serta karekteristik dan keperibadian sang guru dalam melakukan proses pembelajaran.

\section{Learning Management System (LMS)}

Learning management system atau disingkat dengan LMS merupakan suatu perangkat lunak atau software untuk keperluan administrasi, dokumentasi, laporan sebuah kegiatan, kegiatan belajar mengajar dan kegiatan secara online yang terhubung dengan internet seperti elearning [9]. LMS merupakan perangkat lunak yang digunakan untuk membuat materi pembelajaran secara online berbasiskan web dan mengelola kegiatan pembelajaran serta hasilnya. Di dalam LMS juga terdapat fitur-fitur yang dapat memenuhi semua kebutuhan dari pengguna dalam hal pembelajaran.

Saat ini ada banyak jenis LMS yang ditawarkan, setiap jenis LMS memiliki fitur-fiturnya masingmasing yang digunakan dapat berbeda fiturnya. Fiturfitur yang terdapat dalam LMS pada umumnya antara lain:(1) Tujuan dan sasaran; (2) Silabus; (3) Metode pengajaran; (4) Jadwal kuliah; (5) Tugas; (6) Jadwal ujian (7) Daftar referensi atau bahan bacaan (8) Profil dan kontak pengajar; (9) monitoring;

(10) 
Penyampaian materi dan kemudahan akses ke sumber referensi; (11) Bahan presentasi; (12) Contoh ujian yang lalu; (13) Sumber-sumber referensi untuk pengerjaan tugas; (14) Artikel-artikel dalam jurnal online; (15) Penilaian; (16) Ujian online dan pengumpulan feedback; (17) Komunikasi; (18) Forum diskusi online; (19) Mailing list diskusi dan Chatt [9].

Melalui LMS ini, siswa juga dapat melihat nilai tugas dan tes serta peringkatnya berdasarkan nilai tugas maupun tes yang diperoleh. Selain itu, siswa dapat melihat modul-modul yang ditawarkan, mengambil tugas-tugas dan tes-tes yang harus dikerjakan, serta melihat jadwal diskusi secara maya dengan guru, narasumber lain, dan siswa lain. LMS tersedia dalam berbagai macam pilihan

\section{Pembelajaran dengan E- Learning}

E-learning merupakan bentuk pembelajaran jarak jauh yang memanfaatkan teknologi telekomunikasi dan informasi, misalnya internet, video/audiobroadcasting,

video/audioconferencing, CD-ROOM (secara langsung dan tidak langsung). Kegiatan e-learning termasuk dalam model pembelajaran individual. Menurut Loftus kegiatan e-learning lebih bersifat demokratis dibandingkan dengan kegiatan belajar pada pendidikan konvensional, karena peserta didik memiliki kebebasan dan tidak merasa khawatir atau ragu-ragu maupun takut, baik untuk mengajukan pertanyaan maupun menyampaikan pendapat/tanggapan karena tidak ada peserta belajar lainnya yang secara fisik langsung mengamati dan kemungkinan akan memberikan komentar.

Profil peserta e-lerning adalah seseorang yang: (1) mempunyai motivasi belajar mandiri yang tinggi dan memiliki komitmen untuk belajar secara bersungguh-sungguh karena tanggung jawab belajar sepenuhnya berada pada diri peserta belajar itu sendiri; (2) senang belajar dan melakukan kajian-kajian, gemar membaca demi pengembangan diri terus menerus, dan yang menyenangi kebebasan; (3) mengalami kegagalan dalam mata pelajaran tertentu di sekolah konvensional dan membutuhkan penggantinya, atau yang membutuhkan materi pelajaran tertentu yang tidak disajikan oleh sekolah konvensional setempat maupun yang ingin mempercepat kelulusan sehingga mengambil beberapa mata pelajaran lainnya melalui e-learning, serta yang terpaksa tidak dapat meninggalkan rumah karena berbagai pertimbangan.

Menurut Siahaan [10], ada 3 (tiga) fungsi pembelajaran elektronik atau elearning terhadap kegiatan pembelajaran, yaitu:

1. Suplemen (tambahan) merupakan berfungsi sebagai suplemen apabila peserta didik mempunyai kebebasan memilih, apakah akan memanfaatkan materi pembelajaran elektronik atau tidak. Dalam hal ini tidak ada kewajiban/keharusan bagi peserta didik untuk mengakses materi pembelajaran elektronik. Sekalipun sifatnya opsional, peserta didik yang memanfaatkannya tentu akan memiliki tambahan pengetahuan atau wawasan;

2. Komplemen(pelengkap)

Dikatakan berfungsi sebagai komplemen apabila materi pembelajaran elektronik diprogramkan untuk melengkapi materi pembelajaran yang diterima peserta didik di dalam kelas. Sebagai komplemen berarti materi pembelajaran elektronik diprogramkan untuk melengkapi materi pengayaan atau remedial. Dikatakan sebagai pengayaan (enrichment) apabila 
kepada peserta didik yang dapat dengan cepat menguasai/ memahami materi pelajaran yang disampaikan pada saat tatap muka diberi kesempatan untuk mengakses materi pembelajaran elektronik yang memang secara khusus dikembangkan untuk mereka. Tujuannya agar semakin memantapkan tingkat penguasaan terhadap materi pelajaran yang telah diterima di kelas. Dikatakan sebagai program remedial, apabila peserta didik yang mengalami kesulitan memahami materi pelajaran pada saat tatap muka diberikan kesempatan untuk memanfaatkan materi pembelajaran elektronik yang memang secara khusus dirancang untuk mereka. Tujuannya agar peserta didik semakin mudah memahami materi pelajaran yang disajikan di kelas.

3. Substitusi (pengganti)

Dikatakan sebagai substitusi apabila elearning dilakukan sebagai pengganti kegiatan belajar, misalnya dengan menggunakan model-model kegiatan pembelajaran. Ada 3 (tiga) alternatif model yang dapat dipilih, yakni : (1) sepenuhnya secara tatap muka (konvensional), (2) sebagian secara tatap muka dan sebagian lagi melalui internet, atau bahkan (3) sepenuhnya melalui internet.

Ada beberapa pertimbangan untuk menggunakan e-learning, antara lain :

a. harga perangkat komputer semakin lama semakin terjangkau (tidak lagi diperlakukan sebagau barang mewah);

b. Peningkatan kemampuan perangkat komputer dalam mengolah data lebih cepat dan kapasitas penyimpanan data semakin besar;

c. Memperluas akses atau jaringan komunikasi; d. Memperpendek jarah dan mempermudah komunikasi

e. Mempermudah pencarian atau penelusuran informasi melalui internet.

\section{Program Aplikasi Moodle}

Moodle adalah sebuah nama untuk sebuah program aplikasi yang dapat merubah sebuah media pembelajaran kedalam bentuk web. Aplikasi ini memungkinkan siswa untuk masuk kedalam "ruang kelas" digital untuk mengakses materi-materi pembelajaran. Dengan menggunakan Moodle, guru dapat membuat materi pembelajaran, kuis, jurnal elektronik dan lain-lain. Moodle itu sendiri adalah singkatan dari Modular Object Oriented Dynamic Learning Environment. Moodle merupakan sebuah aplikasi Course Management System (CMS) yang gratis dapat di-download, digunakan ataupun dimodifikasi oleh siapa saja dengan lisensi secara GNU (General Public License)

\section{MATERI DAN METODE PELAKSANAAN}

\section{KHALAYAK SASARAN}

Sasaran kegiatan ini adalah guruguru yang tergabung kedalam MGMP SMP IPS Kabupaten Ogan Ilir yang diikuti oleh \pm 20 guru SMA yang mengajar bidang studi IPS, peserta pelatihan ini tersebar dari SMS baik negeri maupun swasta

\section{KETERLIBATAN MAHASISWA}

Pengabdian kepada masyarakat ini mengikutsertakan tiga orang mahasiswa Fasilkom Jurusan Sistem Informasi Unsri sebagai tenaga teknis dan pembantu pelaksana. Mahasiswa yang ikut dalam Pengabdian kepada masyarakat adalah mahasiswa yang akan mengambil Tugas Akhir. Dengan keikutsertaan mahasiswa 
dalam Pengabdian kepada masyarakat ini dapat memberikan wawasan, pengetahuan mahasiswa tentang riset, dan berinteraksi langsung dengan khalayak sasaran, sehingga sangat diharapkan apa yang didapat mahasiswa selama ikut Pengabdian kepada masyarakat ini dapat di terapkan oleh mahasiswa, dalam dalam bersosial dengan masyarakat. Selain itu diharapkan mahasiswa yang ikut Pengabdian kepada masyarakat diharapkan dapat mentransformasi ilmu yang didapat selama kuliah dan dapat bermanfaat untuk masyarakat.

\section{KERANGKAN MASALAH}

\section{PEMECAHAN}

Menghadapi era informasi dan era globalisasi pendidikan melalui Internet menjadi salah satu bentuk pendidikan yang sangat dibutuhkan. Mempersiapkan SDM dengan memberdayakan teknologi informasi terutama dalam menghasilkan tenaga pendidik dan alumni kompetitif menjadi sesuatu yang medesak. Reinassance academic melalui inovasi teknologi untuk meningkatkan keunggulan kualitas akademik menjadi sangat penting sebagai center of excellence melalui teknologi informasi yang menjadi tulang punggung keberhasilan cyber education. Salah satu bentuk cyber education adalah dengan menyediakan perangkat lunak yang dapat membantu meningkatkan kualitas proses pembelajaran berupa aplikasi elearning.

Berangkat dari hal tersebut MGMP IPS SMP Kabupaten Ogan Ilir merencanakan akan melaksanakan kegiatan pelatihan yang dilatarbelakangi oleh adanya keinginan dan kebutuhan tentang pemanfaatan teknologi informasi dan komunikasi yang diharapkan dapat bermanfaat bagi guru dalam meningkatkan kualitas proses pembelajaran. Kegiatan ini akan diikuti oleh guru-guru mata pelajaran IPS sekabupaten Ogan Ilir.
Selaian itu masih rendahnya kompetensi guru dibidang komputer menuntut perlunya dilaksanakan berbagai pelatihan-pelatihan dibidang komputer, sebab kemampuan menggunakan komputer bagi setiap guru mutlak harus dimiliki diera teknologi informasi saat ini. Oleh sebab itu salah satu solusi yang paling tepat dalam meningkatkan kompetensi guru dibidang komputer adalah pelatihan kemampuan komputer dengan judul "Pelatihan Learning Management System Berbasis E-Learning Bagi Guru Yang Tergabung Dalam MGMP IPS SMP Kabupaten Ogan Ilir Sumatra Selatan.

\section{Kegiatan Pelatihan Learning} Management System Berbasis E-Learning Bagi Guru Yang Tergabung Dalam MGMP IPS SMP Kabupaten Ogan Ilir Sumatra Selatan akan dilaksakan selama tiga kali pertemuan, alokasi waktu setiap pertemuan adalah 4 jam atau 240 menit. Rincian metode pelatihan setiap pertemuan adalah:

1. Ceramah/penjelasan singkat 15 menit;

2. Demonstrasi dan peragaan aplikasi 100 menit;

3. Diskusi/tanya jawab 30 menit;

4. Latihan 45 menit;

5. Evaluasi 15 menit.

Kerangka pemecahan masalah dalam Pelatihan Learning Management System Berbasis E-Learning Bagi Guru Yang Tergabung Dalam MGMP IPS SMP Kabupaten Ogan Ilir Sumatra Selatan, diawali dengan pemilihan dan pengembangan silabus dari mata pelajaran IPS terapadu SMP

\section{METODE KEGIATAN}

Metode pendekatan yang ditawarkan kepada khalayak sasaran adalah melalui Pelatihan Learning Management System Berbasis Moodle Bagi Guru Yang Tergabung Dalam 
MGMP IPS SMP Kabupaten Ogan Ilir Sumatra Selatan Menggunakan Program Moodle. Langkah-langkah rencana kegiatan adalah sebagai berikut:

1. Tim Pelaksanaan Pembuatan dokumentasi pelaksanaan pelatihan dengan membuat formulir bagi peserta, seperti formulir isian biodata peserta, formulir daftar hadir, dan formulir isian tanggapan terhadap pelatihan, dan lainlainnya, sebagai bukti pendukung pelaksanaan pelatihan;

2. Tim Pelaksana menyiapkan bahan (modul) pelatihan yang disesuaikan dengan kondisi sosial dan pendidikan khalayak, dan menyiapkan peralatan pelatihan dan sarana demonstrasi Program E-Learning;

3. Demonstrasi Aplikasi oleh khalayak, dengan bimbingan Tim Pelaksana. Tim Pelaksana membina khalayak, dengan diskusi (tanya jawab), membimbing, mengawasi, dan mengevaluasi kegiatan. Tolak ukur kegiatan evaluasi ini meliputi: (a) Daya serap khalayak; (b) Pengumpulan data, informasi, gambar; (c) Penggunaan aplikasi dalam elearining; (d) Proses pengelolaan kontent Materi e-learning; (e) Jumlah data, informasi, gambar dan kualitas media ajar interaktif berbasis e-learning secara keseluruhan yang mampu dihasilkan.

4. Pelaksanaan Pelatihan Learning Management System Bagi Guru Yang Tergabung Dalam MGMP IPS SMP Kabupaten Ogan Ilir Sumatra Selatan dengan garis besar materi meliputi: (a) Pengenalan dan Instalasi Moodle; (b) User, Interface Moodle; (c) Membuat Acount Guru; (d) Membuat Acount Siswa; (e) Upload Materi, Download Materi; (f) Ujian Online; (g) Nilai Online; (i) Forum Guru.

5. Metode pelaksanaan Pelatihan Learning Management System Bagi Guru Yang Tergabung Dalam MGMP IPS SMP Kabupaten Ogan Ilir Sumatra Selatan, adalah sebagai berikut : a) Memberikan penjelasan kepada guru-guru perihal pembuatan perangkat ajar menggunakan moodle dalam peningkatan kualitas proses pembelajaran.

b) Memberikan pelatihan kepada guru-guru untuk dapat menggunakan perangkat moodle.

c) Memberikan peragaan kepada guru-guru presentasi mata pelajaran IPS SMP berbasis e-learning.

\section{RANCANGAN EVALUASI}

Pada setiap tahap kegiatan dilakukan evaluasi dengan cara tanya jawab, pengamatan, dan pengisian kuisioner oleh khalayak sasaran. Evaluasi ini menyangkut penyerapan materi, demonstrasi (peragaan) pengelolaan dan pembuatan media ajar berbasis e-learning. Pada kegiatankegiatan evaluasi ini, tim pelaksana mengusahakan adanya masukan-masukan, tanya jawab serta diskusi secara non formal dengan khalayak untuk mengatasi masalah yang mungkin muncul dan untuk menunjang keberhasilan tujuan dan manfaat kegiatan. Tahapan evaluasi yang dilakukan adalah sebagai berikut:

Tabel I.1 Tolak Ukur Keberhasilan Pangabdian Masyarakat

\begin{tabular}{|c|c|}
\hline Kegiatan & Tolak ukur \\
\hline $\begin{array}{c}\text { Peninjauan dan } \\
\text { mengusahakan } \\
\text { adanya tanya } \\
\text { jawab/diskusi } \\
\text { terhadap } \\
\text { khalayak }\end{array}$ & $\begin{array}{l}\text { 1. Persiapan sarana } \\
\text { kegiatan; } \\
\text { 2. Penyerapan materi } \\
\text { dalam menunjang } \\
\text { pengelolaan dan } \\
\text { penguasaan } \\
\text { aplikasi untuk } \\
\text { membuat media } \\
\text { ajar berbasis E- } \\
\text { Learning; } \\
\text { 3. Penggunaan } \\
\text { aplikasi } \\
\text { demontrasi saat } \\
\text { (peragaan) } \\
\text { pembuatan media } \\
\text { ajar berbasis E- }\end{array}$ \\
\hline
\end{tabular}




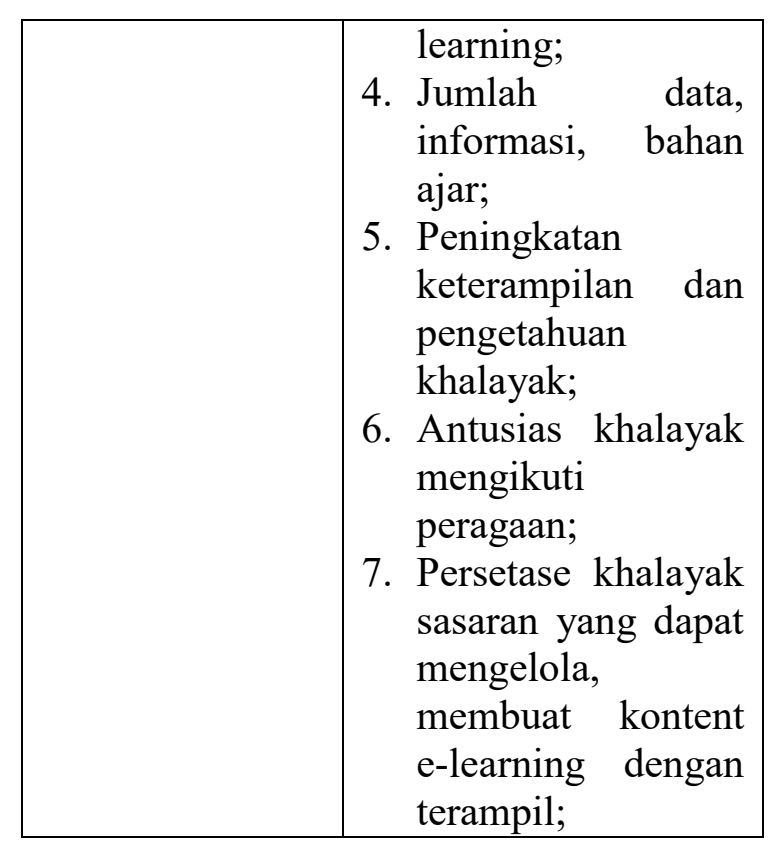

Evaluasi dilakukan pada akhir kegiatan berupa tanya jawab dan praktek membuat media pembelajaran. Indikator pencapaian tujuan apabila sekurangkurangnya $80 \%$ dari khalayak sasaran dapat membuat media media ajar berbasis e-learning.

\section{HASIL DAN PEMBAHASAN}

\section{PELAKSANAAN KEGIATAN}

Kegiatan Pelatihan Learning Management System Berbasis E-Learning Bagi Guru Yang Tergabung Dalam MGMP IPS SMP Kabupaten Ogan Ilir Sumatra Selatan, dapat dilaksanakan sesuai dengan harapan tim. Kegitan pengabdian kepada masyarakat dilaksanan pada sabtu dan minggu yaitu dari jam 08.30 sd 14.00 WIB. Kegiatan pengabdian masyarakat dilaksanakan di laboraturium lantai dasar diploma komputer fakultas ilmu komputer Unsri. Pada kegiatan kegiatan pengabdian masyarakat ini diikuti oleh sekitar \pm 20 guru yang tergabung dalam MGMP IPS Kab. Ogan Ilir. Selama pelaksanaan kegiatan tersebut, peserta sangat antusias sekali dengan adanya kegiatan pelatihan pembuatan media ajar berbasis video ini. Karena di era modern dan serba digital, sudah selayaknya guru mengembangankan keterampilan dalam membuat media ajar berbasis video, sehingga pembelajaran lebih menarik dan interaktif. Selama kegiatan berlangsung, tim pelaksana dibantu oleh dua orang mahasiswa.

\section{REALISASI MASALAH}

PEMECAHAN

Seperti yang sudah diuraikan pada bab pendahuluan bahwa, rendahnya hasil belajar siswa salah satunya disebabkan karena guru jarang sekali menggunakan media animasi dalam proses pembelajaran. Dimana proses pembelajaran masih berlangsung secara konvensional, aktivitas menulis lebih dominan dilakukan oleh guru dalam mengajar. Sehingga pembelajaran kurang menarik dan kurang interaktif. Alasan utama mengapa para guru tidak menggunakan media animasi dalam pembelajaran antara lain karena para guru belum mengerti, belum mamahami bagaimana cara membuat media ajar berbasis animasi. Karena guru adalah SDM yang terdidik, potensi tersebut dapat ditingkatkan dengan meningkatkan pengetahuan dan pemahaman serta kemampuan guru dalam pengelolaan bidang komputer. Bantuan yang diperkirakan paling efisien sesuai keterbatasan waktu, dana, dan tenaga adalah Pelatihan Learning Management System Berbasis E-Learning Bagi Guru Yang Tergabung Dalam MGMP IPS SMP Kabupaten Ogan Ilir Sumatra Selatan.

\section{RESPON, TANGGAPAN DAN UMPAN BALIK}

Berdasarkan hasil diskusi secara langsung dengan peserta pelatihan, didapat hasil bahwa peserta sangat antusias sekali dengan adanya Pelatihan Learning Management System Berbasis E-Learning Bagi Guru Yang Tergabung Dalam MGMP IPS SMP Kabupaten Ogan Ilir Sumatra Selatan. Selain itu juga dapat dilihat dari hasil kerja peserta pada saat 
Pelatihan Learning Management System Berbasis E-Learning Bagi Guru Yang Tergabung Dalam MGMP IPS SMP Kabupaten Ogan Ilir Sumatra Selatan. Pada saat tanya jawab dengan peserta, ada beberapa peserta menyampaikan keinginan kembali untuk diadakan pelatihan selanjutnya. Karena sepertinya keinginan mereka sangat besar sekali untuk menciptakan pembelajarn berbasis multimedia sehingga proses pembelajaran menjadi lebih interaktif dan manarik.

Menanggapi keinginan peserta, kami tim pengabdian menyampaikan insya allah tahun selajutnya akan mengadakan pelatihan kembali dan mengundang mereka sebaga khalayak dalam kegiatan tersebut. Disampin hal tersebut, tim pelaksana memberikan tugas kepada masing-masing peserta untuk membuat media ajar sesuai dengan materi yang disampaikan disekolah masing-masing. Selain itu juga untuk memonitoring, pada saat peserta mau mengambil sertifikat pelatihan, peserta diwajibkan telah menyumpulkan tugas mandiri tersebut.

\section{HASIL EVALUASI DAN PEMBAHASAN}

Dimana hasil yang dicapai sesuai dengan stardart yaitu sekitar $80 \%$ peserta berhasil dalam pelatihan tersebut. Berikut contoh hasil yang telah dibuat oleh peserta dalam web http:/www.elearningmgmpipsoi.org/. seperti terlihat pada gambar 3

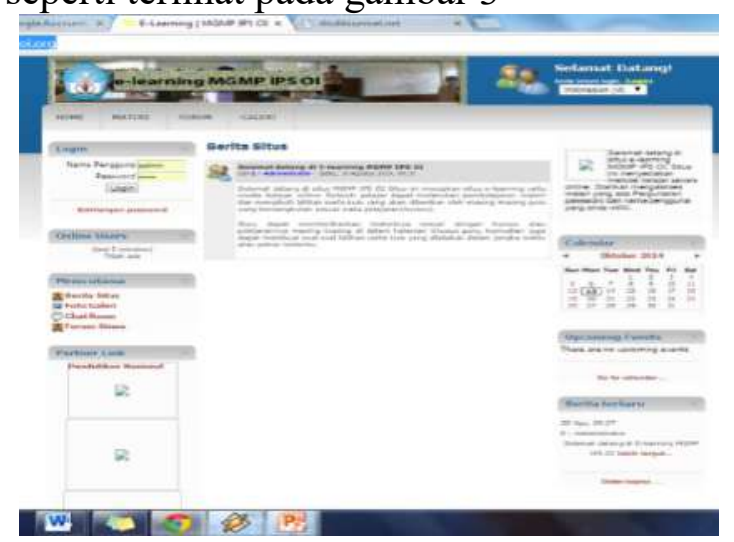

Gambar 1 Hasil pelatihan 1
Untuk login sebagai admin hanya bisa dilakukan oleh ketua MGMP IPS SMP Kabupaten Ogan Ilir Sumatra Selatan. Seperti dilihat pada gambar 4

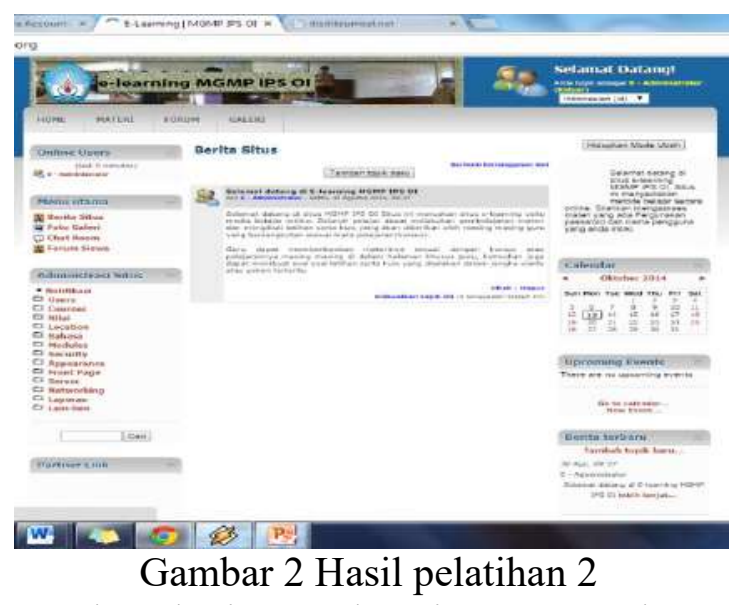

Untuk login sebagai guru harus menggunalan login guru, seperti terlihat pada gambar 5
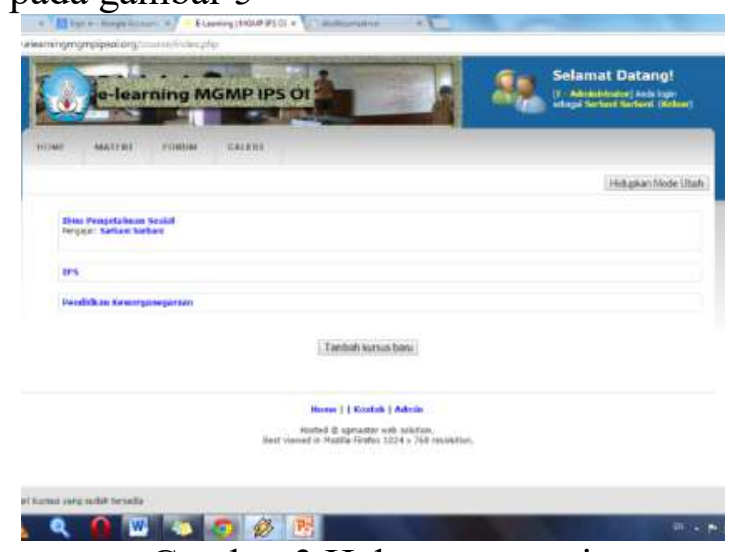

Gambar 3 Halaman materi

Untuk melihat isi dari materi klik IPS, maka akan seperti terlihat pada gambar 4 .

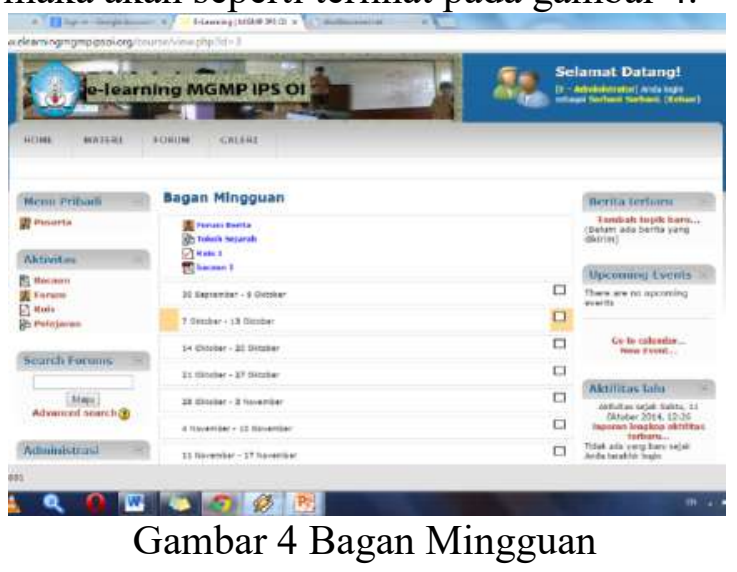

PEMBAHASAN

72 www.jurnal.umb.ac.id 
Kegiatan Pelatihan Learning Management System Berbasis E-Learning Dengan Program Moodle Bagi Guru Yang Tergabung Dalam MGMP IPS SMP Kabupaten Ogan Ilir Sumatra Selatan. Kegiatan pelatihan ini diikuti oleh \pm 20 peserta dari gabungan MGMP IPS SMP Kabupaten Ogan Ilir. Berdasarkan hasil diskusi dengan beberapa peserta bahwa mereka sangat antusias dalam mengikuti pelatihan ini. Hal ini terbukti dari jam 08.00 wib, lebih dari sebagian peserta sudah berada di lokasi pelatihan. Hal ini sangat luar biasa sekali, padahal berdasarkan undangan yang kami berikan, acara akan dimulai jam 08.30 wib. Kegiatan pelatihan ini dimulai dengan cara pengenalan internet untuk mencari materimateri yang berhubungan dengan pelatihan seperti gambar, hasil rekaman, lagu dan materi ajar. Dan seterusnya dilanjutkan sesuai dengan materi pelatihan yang ada pada modul pelatihan.

Kegiatan Pelatihan Learning Management System Berbasis E-Learning Dengan Program Moodle Bagi Guru Yang Tergabung Dalam MGMP IPS SMP Kabupaten Ogan Ilir Sumatra Selatan, alhamdulillah berjalan dan sukses sesuai dengan harapan tim pengabdian dan peserta pelatihan. Berdasarkan dari hasil diskusi secara langsung pada saat pelatihan berlangsung, peserta sangat senang dan semangat sekali mengikuti pelatihan ini. Hal ini diungkapan oleh salah satu peserta bahwa untuk era digital, memang guruguru sekarang harus dapat meningkatkan keterampilan dalam mebuat bahan ajar berbasis e-learning untuk dapat menarik minat belajar siswa. Dari hasil pelatihan ini, peserta selain mendapatkan pelatihan langsung bagaimana cara membuat bahan media ajar berbasis multimedia dan di upload di web e-learning oleh tim pengabdian kepada masyarakat, peserta juga mendapatkan program www.elearningmgmpipsoi.org dan modul pembuat media ajar yang dibuat oleh tim pelaksana. Dengan program tersebut dan adanya modul sebagai panduan dalam pembuatan media ajar, maka peserta dapat membuat media ajar di sekolahnya masing-masing dan dapat menyebarluaskan ketrampilan mereka kepada guru-guru mata pelajaran yang lain. Bahkan guru yang ikut palatihan tersebut dapat menjadi mentor atau tutor untuk guru yang lain dalam membuat media ajar berbasis multimedia.

Dari hasil pengamatan secara langsung dan dan hasil diskusi antara tim pengabdian dan peserta, maka pelatihan dapat dikatakan berhasil dan sukses hal ini terlihat semangat dan hasil yang telah dicapai peserta pada saat pelatihan, yaitu sekitar $80 \%$ peserta sudah bisa membuat bahan ajar berbasis e-learning. Sedangkan $20 \%$ lagi mereka sudah bisa tetapi mereka masih melihat modul panduan. Dari kegiatan pelatihan ini besar harapan peserta untuk di lain waktu akan diadakan pelatihan dengan materi yang berbeda.

\section{KESIMPULAN DAN SARAN}

\section{KESIMPULAN}

Berdasarkan hasil kegiatan Pelatihan Learning Management System Berbasis E-Learning Bagi Guru Yang Tergabung Dalam MGMP IPS SMP Kabupaten Ogan Ilir Sumatra Selatan, maka dapat diambil kesimpulan sebagai berikut:

1. Dari semua peserta yang mengikuti pelatihan, $80 \%$ sudah berhasil dan bisa membuat bahan media ajar berbasis animasi dan diupalod pada web elearning;

2. $20 \%$ peserta lainya sudah dapat membuat bahan media, tetapi masih melihat modul pelatihan;

3. Dari hasil diskusi dengan peserta, peserta yang mengikuti pelatihan tersebut, akan mengajarkan kepada guru-guru yang lain di masingmasing sekolah mereka, bahkan 
mereka akan mengadakan pelatihan sendiri di sekolahnya masingmasing;

4. Dengan adanya pelatihan tersebut, maka dapat meningkatkan profesinal guru yang sudah memiliki sertifikat, karena salah satu syaratnya guru harus menguasai ICT sebagai salah satu media pembelajaran.

\section{DAFTAR PUSTAKA}

[1] Djamarah, S.B. 1995. Prestasi Belajar dan Kompetensi Pengajar. Surabaya : Usaha Nasional

[2] Gardner, Susannah., Birley, Shane., 2008, "Blogging For Dummies 2nd Edition", John Wiley \& Sons, New York.

[3] Hudoyo, Herman. 1990. Strategi Mengajar Belajar Matematika. Malang : IKIP Malang

[4] Pujadi, T. 2008. Blog Dan Rss Sebagai Sarana Kolaborasi Untuk Meningkatkan Pemerataan Akses Belajar. Makalah disampaikan pada International Conference ICT Education UNY Yogyakarta

[5] Sudjana, Nana \& Rivai, Ahmad. 2002. Media Pengajaran. Bandung : Sinar Baru Algensindo

[6] Sadiman, Arif S, et. Al. 2002. Media Pemdidikan: Pengertian, Pengembangan dan Pemanfaatannya. Jakarta : Raja Grafindo Persada.

[7] Surya, M. (2006). Potensi Teknologi Informasi dan Komunikasi Dalam Peningkatan Mutu Pembelajaran di Kelas. Makalah dalam Seminar Pemanfaatan TIK untuk Pendidikan Jarak Jauh dalam Rangka Peningkatan Mutu Pembelajaran. Diselenggarakan oleh Pustekkom Depdiknas, tanggal 12 Desember 2006 di Jakarta. 